\title{
NUMERICAL STRENGTH ANALYSIS OF THE LOAD-BEARING FRAME OF A PALLETIZING ROBOT'S UNIVERSAL HEAD
}

\section{NUMERYCZNA ANALIZA WYTRZYMAŁOŚCI RAMY NOŚNEJ UNIWERSALNEJ GŁOWICY ROBOTA PALETYZUJĄCEGO*}

\begin{abstract}
The paper deals with numerical strength analysis of the load-bearing structure of an industrial robot's head used for palletization of sacks. The calculations were performed with the Finite Element Method (FEM), enabling reconstruction of the real service conditions in the process of palletization. It was assumed, that the head was adapted to lay two sacks of maximal dimensions $800 \times 500 \times 140 \mathrm{~mm}$ and a mass of up to $50 \mathrm{~kg}$ at a time. The currently exploited palletizing heads are heavy, which essentially increases the costs of the palletization process. The aim of the study was a numerical analysis of the existing head of the palletizing robot, leading to design of a structure having optimized maintenance parameters. The conducted research on decreasing the mass of the palletizing robot's head are important because of the industrial robot's load-bearing capacity, its effectiveness and the costs of the palletization process.
\end{abstract}

Keywords: FEM, palletization, robot's head, load-bearing frame, modelling, grasper.

\begin{abstract}
W prezentowanej pracy zajęto się numeryczna analiza wytrzymałościowa ustroju nośnego głowicy robota przemysłowego, która stuży do paletyzacji worków. Obliczenia prowadzono z zastosowaniem metody elementów skończonych, umożliwiającej odwzorowanie rzeczywistych warunków eksploatacyjnych pracy robota w procesie paletyzacji. W obliczeniach przyjęto, że głowica jest przystosowana do układania dwóch worków jednocześnie o maksymalnych wymiarach gabarytowych: $800 \mathrm{~mm}, 500 \mathrm{~mm}, 140 \mathrm{~mm}$ oraz masie do $50 \mathrm{~kg}$. Stosowane obecnie głowice paletyzujące sa ciężkie, co znacznie podnosi koszty procesu paletyzacji. Celem pracy była analiza numeryczna istniejacej głowicy robota paletyzującego, na podstawie której możliwe będzie zaprojektowanie konstrukcji o zoptymalizowanych parametrach eksploatacyjnych. Prowadzone prace nad redukcja masy własnej glowicy robota paletyzujacego sa istotne ze względu na nośność robota przemystowego, wydajność oraz koszt procesu paletyzacji.
\end{abstract}

Slowa kluczowe: MES, paletyzacja, głowica robota, rama nośna, modelowanie, chwytak.

\section{Introduction}

The advancing process of packaging and palletizing automation [1-6] caused a big demand of universal and lightweight graspers of the industrial robot's heads, being able to carry and lay down ladings on transportation pallets. Among main tasks of the graspers one can distinguish catching a manipulated object, holding it during moving and proper releasing at the place of destination. The grasper is a tool adapted to the robot's arm and is a separate assembly of interacting elements [7]. The proper catching of the object depends among others on its shape, mass, center of mass location, surface quality in the very place of grasping, prehensile possibilities of the grasper and the misalignment of the ready to move object with respect to the pick-up point.

The second phase of the grasper service is holding the object during manipulation. Within the service range at that phase the motion induced accelerations occur. Their values have essential effect on the burden of the analysed object's load-bearing elements. The last stage of service is a process of the detail release at the destination location, which starts with reaching the end position and precise stopping. If the detail's release takes place with no obstacles (the anti-collision systems does not react) the robot retreats in order to move back from the manipulated object.

The object of research was a palletizing robot's head exploited in the process of sacks packaging. The analyzed device was an expanded multifunctional grasper equipped with fully automated control - the Wikpol's palletizing head given in Fig. 1.

The considered head consisted of several key-elements: the attachment terminal, the load-bearing frame, the movable frame, the grasper's fork, as well as the bottom and the side holdfast. The grasper can be included in the group of forceful-shaped ones. The sacks transported by the head are raised with the fork being a system of jaws closing at the sacks in the bottom. During transportation the sacks lay on the fork and are simultaneously held with the side holdfast in horizontal direction and with the top holdfast in vertical direction. From the point of view of the prehensive endings' degrees of freedom the presented head can be included in the vise-like graspers family, because of the horizontal movement of the fork. The movable elements of the head are moved with standardized pneumatic actuators. The head's frame is attached directly to the robot having a total lading capacity of $250 \mathrm{~kg}$. The palletizing head in its current design has its own

(*) Tekst artykułu w polskiej wersji językowej dostępny w elektronicznym wydaniu kwartalnika na stronie www.ein.org.pl 


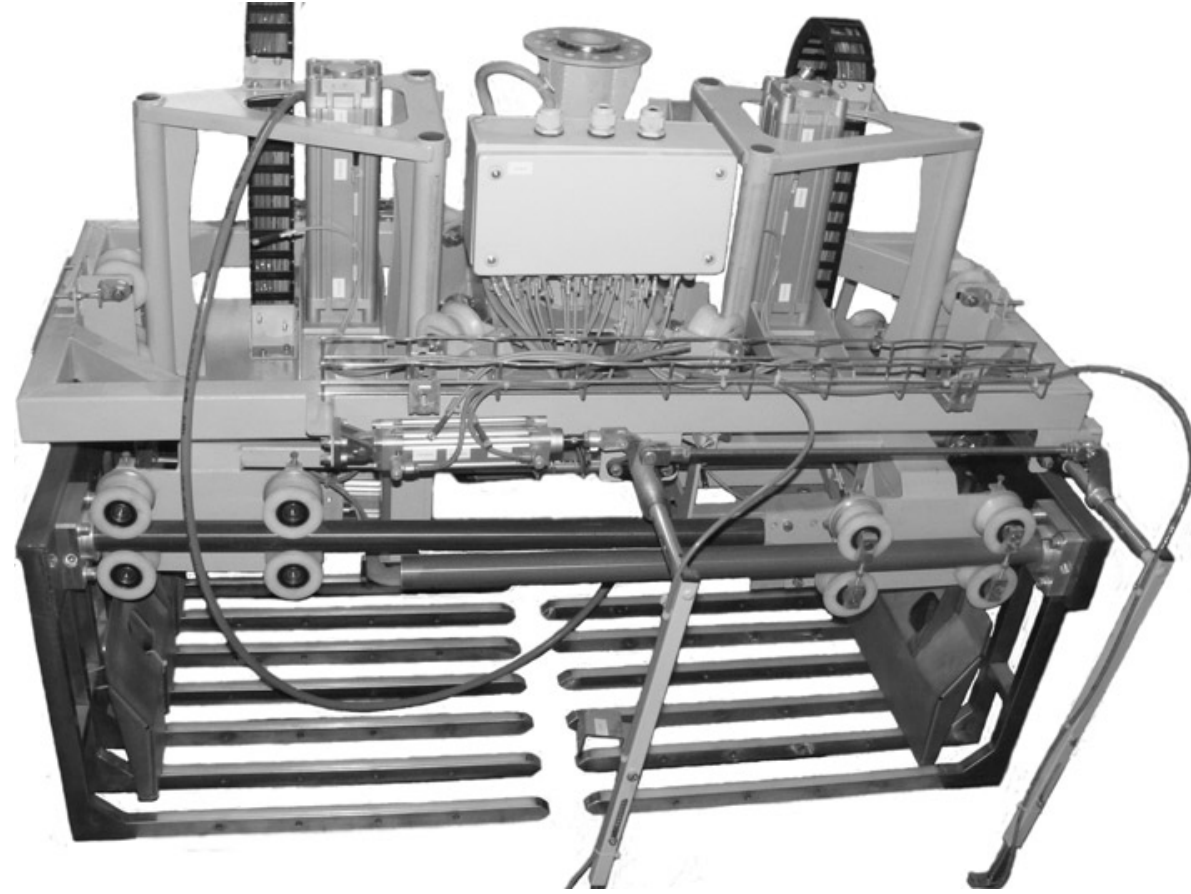

Fig. 1. Palletizing head produced by the ,Wikpol” company

\section{Research object and scope}

The object of research were the load-bearing elements of the Wikpol's palletizing head, without the control system components and the structural details unimportant from the strength point of view. The geometric model of the analysed object (Fig. 2) was developed in the form of an assembly based on the device technical documentation with the use of the CATIA V5 CAD software. The elaborated model of the load-bearing frame of the palletizing head reflected the device configuration corresponding to service conditions occurring during transportation of lading. It applies first of all to the relative configuration of the movable frames and the load-bearing frame, as well as to setting the lading's and the fork's center of mass in the conditions of service.

The developed geometrical model of the palletizing head was a basis for discrete model enabling execution of numerical calculations with the Finite Element Method. The process of geometrical model's discretization was conducted with the C3D8R eight- noded solid elements mass of $200 \mathrm{~kg}$, which allows it to carry - together with the dedicated manipulator - two sacks of $25 \mathrm{~kg}$ mass.

The aim of the conducted research was to design a lightweight load-bearing frame having high stiffness and thus able to carry simultaneously two sacks of $50 \mathrm{~kg}$ mass each. The project of the new head was a modification of the existing construction through elimination of the low effort elements responsible for significant mass increase of the object. To achieve this the heavy elements, i.e. the attachment terminal and the load-bearing frame were subjected to a detailed strength analysis [8-10]. The whole modelling process, as well as a detailed numerical strength calculations were performed with the Finite Element Method (FEM) in the ABAQUS ${ }^{\circledR}$ commercial software environment [11-12].

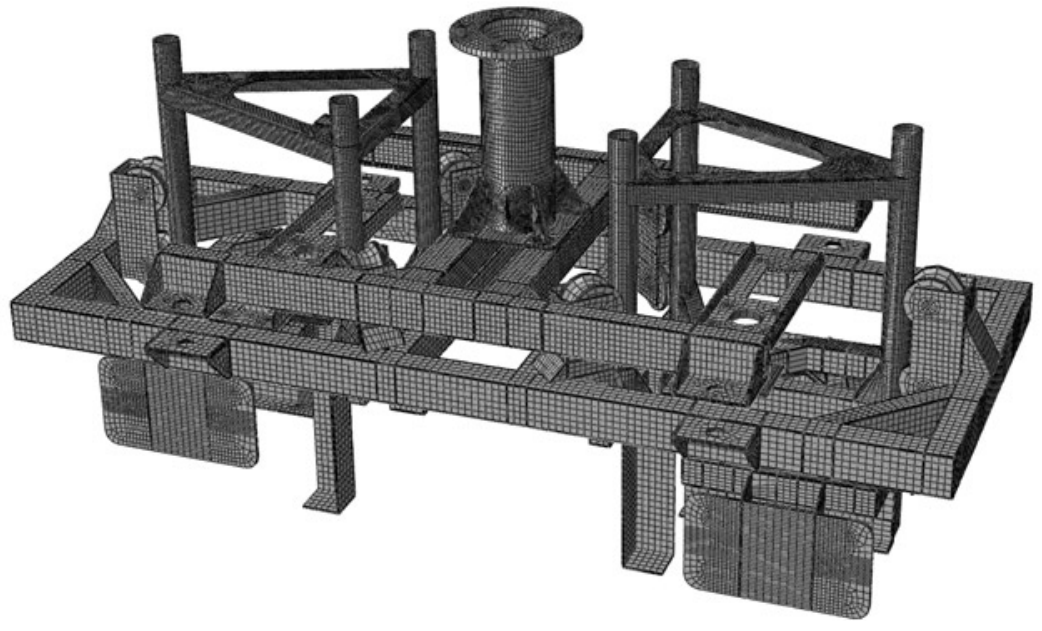

Fig. 3. Discrete model of the palletizing head's frame with boundary conditions and applied load

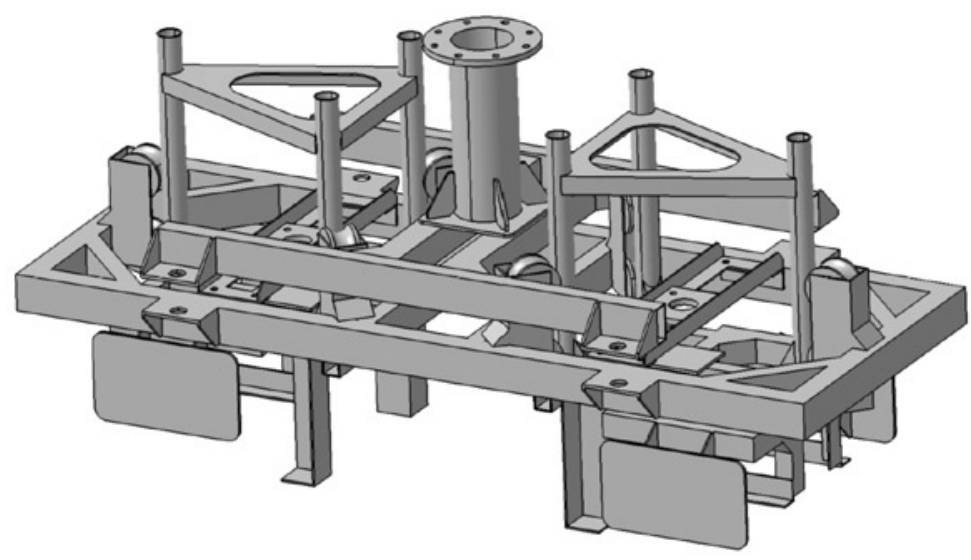

Fig. 2. Geometrical model of the load-bearing frame of the palletizing head of reduced integration and having three translational degrees of freedom at each node [13-18]. The applied finite elements were of first order. For the purpose of providing the compatibility between the overall mass of the palletizing head and its elaborated discrete model it was necessary to take into consideration the mass of rejected elements (excluded from the geometrical model) giving $58.2 \mathrm{~kg}$ in total. The above mentioned elements were included in the model as point masses assigned to the respective regions of the frame at appropriate locations. The elaborated discrete model of the palletizing head taking into account the reciprocal contact interactions among respective parts of the model and providing their appropriate cooperation is shown in Fig. 3.

The model of the accepted boundary conditions assumed that the connection of the palletizing head with the robot's bunch was encastered. Having this in target all the translational degrees of freedom of the nodes at the head's attachment surface were restrained. It was assumed, that the head was loaded with no ex- 
ternal forces except the carried lading's weight and the device's own mass. For lack of a model of the fork, on which the sacks lay directly during transportation, in the analysis a sum of the fork and the sack masses was accepted and their common center of mass was determined with appropriate CATIA V5 software functions. The calculations considering a loading case, in which the head transported a lading composed of two sacks with the total mass of $100 \mathrm{~kg}$ were performed. In the calculations the weight of the tested object itself was allowed for, whereas the load simulating manipulating moves of the robot were included through introduction of acceleration of $40 \mathrm{~m} / \mathrm{s}^{2}$ acting in horizontal direction [19-20], which corresponded with maximal value of retard obtained during an emergency stop of the robot.

In the numerical calculations the linear elastic material model was accepted as during the head's exploitation no permanent deformations took place. All the load-bearing elements of the frame were assumed to be made of steel with the following mechanical characteristics: Young modulus $E=$ $210 \mathrm{GPa}$, Poisson ratio $v=0.3$ and mass density $\rho=7860 \mathrm{~kg} / \mathrm{m}^{3}$. The yield stress essential in the effort assessment of the head frame's loadbearing elements was $R_{\mathrm{e}}=235 \mathrm{MPa}$. It was additionally assumed, that in the model large displacements could occur, making the problem geometrically nonlinear. In the performed calculations the incremental-iterative Newton-Raphson method was used [17-18].

\section{Numerical results}

The performed calculations enabled determination of the Huber-Mises-Hencky equivalent stress distributions [13-15] in the load-bearing elements of the head, as well as determination of the head's displacements in case of the emergency robot stopping. The equivalent stress results are given in Fig. 4, whereas the nodal displacements - in Fig. 5. The obtained general level of the equivalent stress in the elements of the head did not exceed $\sigma \approx 235 \mathrm{MPa}$, whereas the observed local cumulations of the stress near the head pipe's stiffening ribs indicated substantial exceeding of the yield stress in these regions. The scale of the displayed stress contours was limited to $235 \mathrm{MPa}$ in order to gain a more empha-

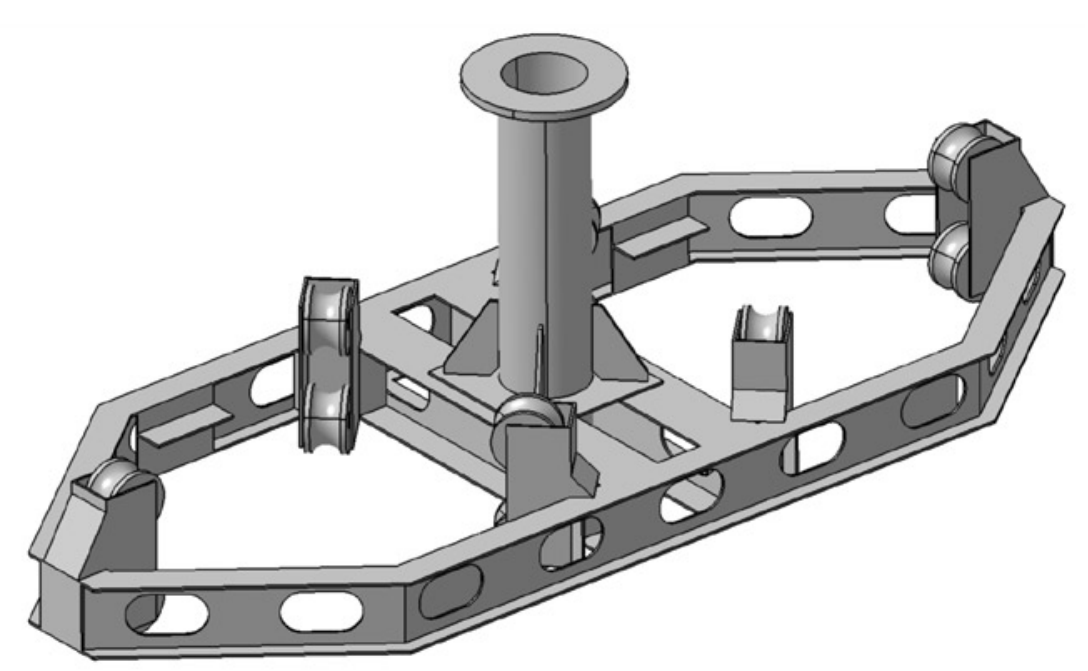

Fig. 5. Nodal displacements of the numerical model

sized picture of the stress contour. Maximal nodal displacement in the model occurred place at the movable frame's boundaries and reached $18 \mathrm{~mm}$.

Typical behaviour of the examined load-bearing structure observed in the model was an occurrence of high stress in the attachment terminal, at simultaneous very low stress in the load-bearing frame.

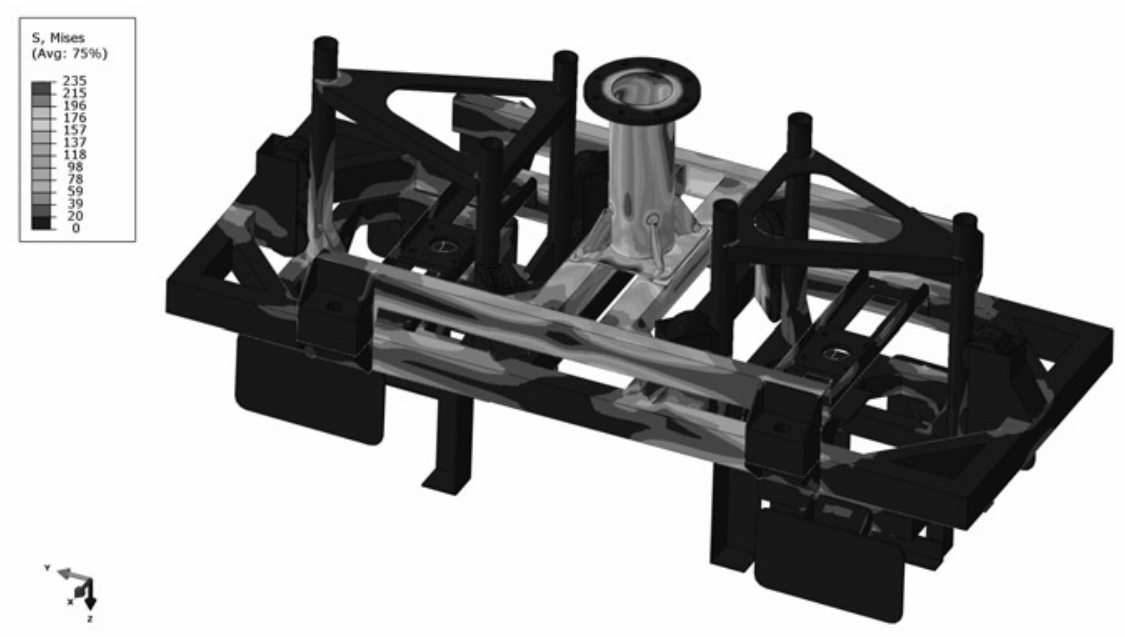

Fig. 4. The Huber-Mises-Hencky equivalent stress contour
As the terminal is responsible only for the grasper connection to the robot's bunch, it was neglected in the model. Instead, the connecting functionality was assigned to the load-bearing frame. Elimination of the attachment terminal model was made in practice by elongation of the pipe fixing it to the robot's bunch in order to join it with the load-bearing frame without changing the distance between the frame and the bunch. Moreover, the evidently low effort level of the closed-section profiles constituting the load-bearing frame was the reason to make an attempt to replace them with open-section profiles having a form of I-beams. In the Ibeams' webs holes were made that shouldn't weaken these elements' strength, whereas they would result in mass reduction. In the proposed structural design a steel with higher (compared 


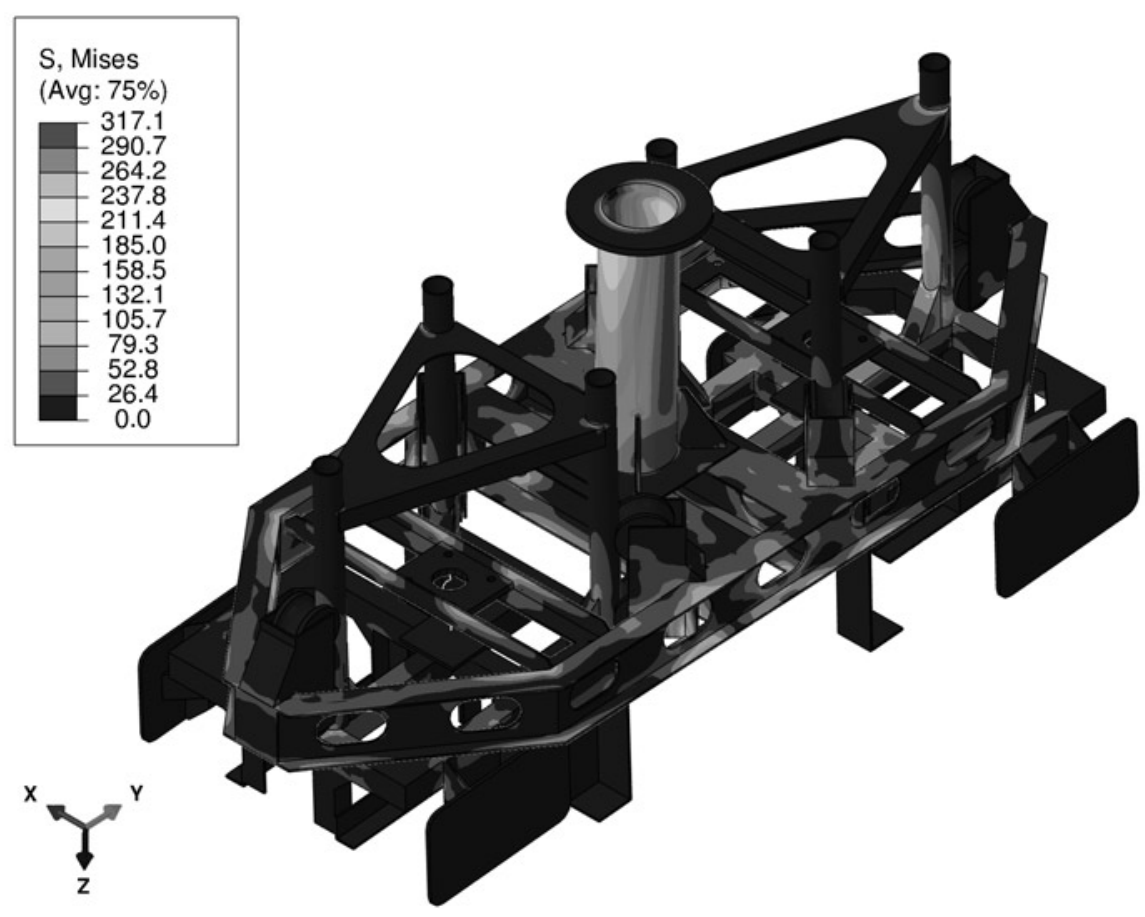

Fig. 7. The equivalent H-M-H stress field in the modified load-bearing frame

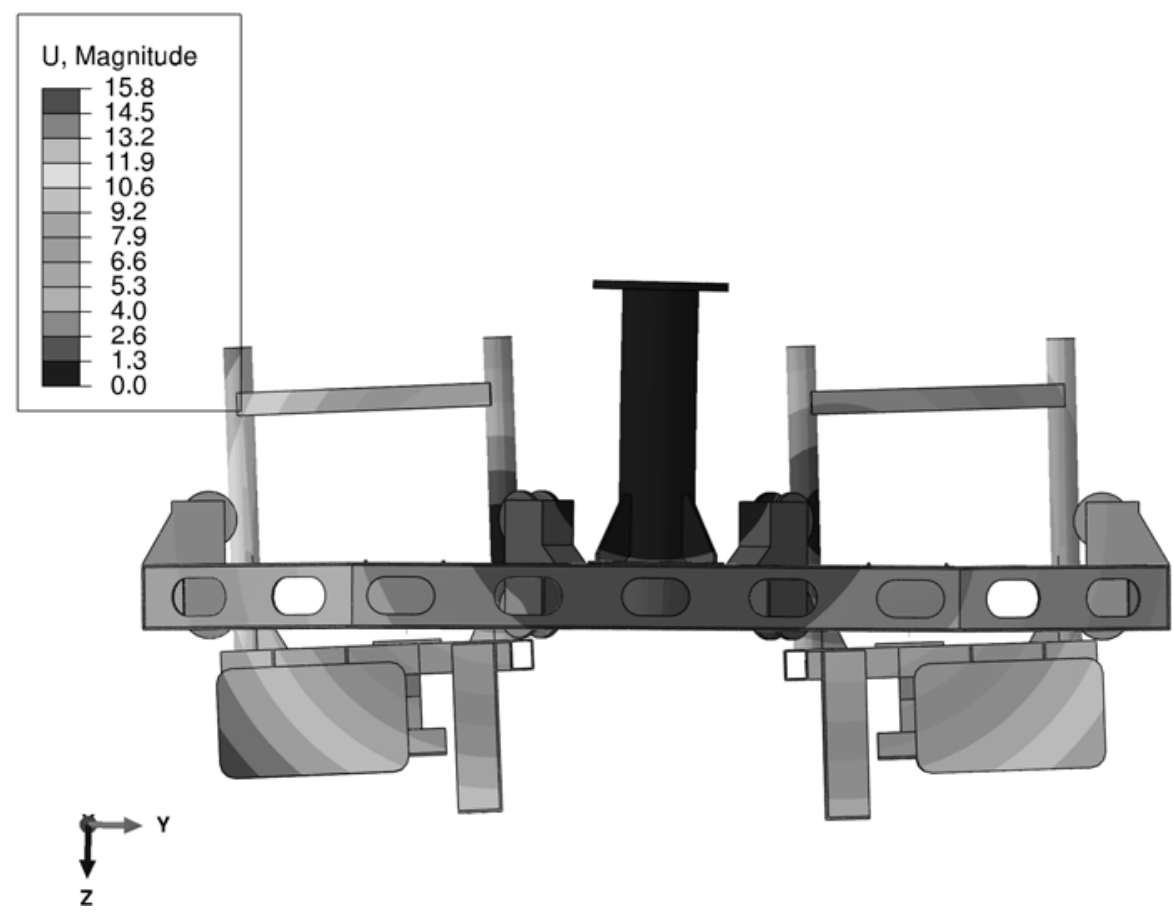

Fig. 8. Nodal displacements of the modified load-bearing frame the H-M-H hypothesis in the load-bearing frame overcame the accepted yield stress of the material $R_{\mathrm{e}}=350 \mathrm{MPa}$ and in parallel a definitely more uniform effort in all the load-bearing elements of the structure was attained. It is well visible, that the holes made in the frame did not cause additional stress concentration (even though their size was large) and - advantageously - they essentially reduced the load-bearing frame's mass. The maximal stress values occurred in the internal roll set of the movable frame and equaled $\sigma=317 \mathrm{MPa}$. Such a value does not jeopardize the device's safe service but is an indication to consider modification of that element as well.

Analysis of the nodal displacements (Fig. 8) justifies a statement that maximal displacements were $15.8 \mathrm{~mm}$. This means that changing the structural design of the load-bearing frame decreased the maximal value of nodal displacements in comparison with the original model. The load-bearing frame's re-design gave significant advantage in the form of the head's mass reduction. The performed numerical analysis allowed elimination of the outer frame of the head, in which the effort of the load-bearing elements was very low. The proposed design reached the assumed aims and essentially simplified the whole device's construction.

\section{Conclusions}

The way of the FEM-based modelling of the load-bearing structures presented in the current paper enabled conducting analysis of deformation and effort of the load-bearing elements subjected to a complex external loading. This is extremely significant in case of searching for new structural design, when at the stage of designing complicated machines and mechanisms too many unknown parameters occur. Recognition of the stress field in the load-bearing elements of the structure is thus a question of primary importance, allowing an assessment of the accepted structural design. Numerical analyses enable also optimization of the model parameters in order to choose the best solution from the point of view of ability to carry the defined service loads. The performed analysis enabled an assessment of the proposed structural design, being a basis for introducing the necessary modifications of the construction details in order to obtain the optimal solution in this sense.

The FEM numerical calculations of the load-bearing frame of the palletizing robot' head to the previous construction) yield strength equal $R_{e}=350 \mathrm{MPa}$ was accepted. In Fig. 6 the modified load-bearing frame is shown, which allows to reduce the palletizing head's mass by ca. $11 \mathrm{~kg}$ and simultaneously simplifies the whole head's design essentially.

The process of discretization of the geometrical model, as well as the parameters' identification of the numerical analysis of the modified head frame was performed identically, as in the case of the frame model before modifications.

The performed calculations proved essential improvement of the degree of effort in the particular load-bearing elements of the head's frame. In the considered case the equivalent stress level according to proved, that its load-bearing capacity could be significantly increased at simultaneous reduction of its own mass. In the presented case the computed equivalent stress contours showed that many load-bearing elements of the head exhibited a very low effort. The modification of the load-bearing frame allowed essential reduction of the elements' mass $-27.5 \%$ with respect to the basic variant, keeping the stiffness and the functionality of the structure. It is fairly important from the maintenance point of view, because it enables a significant increase in the effectiveness of the device through increasing the palletization possibilities of higher lading weight. The developed 3D solid model 
simulated the service conditions of all the elements very well and enabled subsequent modifications of not only the load-bearing frame, but also of the whole device, i.e. the universal head of the palletizing robot. The performed study enabled an assessment of the proposed structural design and as such was a basis for introduction of the necessary particular modifications in order to obtain the optimal design within that scope. The presented modelling procedure is universal and can be applied to different-type robot heads.

\section{Acknowledgement}

The research was supported by the statutory resources allowed to the Department of Applied Mechanics, Lublin University of Technology as "The Grant for Young Researchers" No. 30/MN/2014.

\title{
References
}

1. Abaqus 6.13 analysis user's manual, Dassault Systèmes, 2013.

2. Abdou G., Lee E.: Physical model for robotics palletization. Computers in Industry 1991;16(3):255-266, http://dx.doi.org/10.1016/01663615(91)90063-F.

3. Balasubramanian R.: The pallet loading problem: A survey. International Journal of Production Economics, 1992;28(2):217-225, http:// dx.doi.org/10.1016/0925-5273(92)90034-5.

4. Belforte G., Deboli R., Gay P., Piccarolo P., Ricauda Aimonino D.: Robot Design and Testing for Greenhouse Applications. Biosystems Engineering 2006;95(3):309-321, http://dx.doi.org/10.1016/j.biosystemseng.2006.07.004.

5. Ehab Ellobody, Ran Feng and Ben Young: Finite Element Analysis and Design of Metal Structures. Butterworth-Heinemann, Waltham, USA, 2014.

6. Ferdynus M.: An energy absorber in the form of a thin-walled column with square cross-section and dimples. Eksploatacja i Niezawodnosc - Maintenance and Reliability 2013;3(15):253-258.

7. Friedel Hartmann Casimir Katz: Structural Analysis with Finite Elements. Springer-Verlag Berlin Heidelberg 2007.

8. Guo-Qiang Li and Jin-Jun Li: Advanced: Analysis and Design of Steel Frames. John Wiley \& Sons Ltd, The Atrium, Southern Gate, Chichester, West Sussex, England, 2007.

9. Guo-Qiang Li, Jin-Jun Li: Advanced Analysis and Design of Steel Frames. John Wiley \& Sons Ltd, The Atrium, Southern Gate, Chichester, 2007, http://dx.doi.org/10.1002/9780470319949.

10. Hernan M.: An introduction to Automated Palletizing. Anderson Technical Services, Ohio 2000.

11. Kathryn A. Dowsland, William B. Dowsland: Invited review. Packing problems. European Journal of Operational Research 1992;56(1):214, http://dx.doi.org/10.1016/0377-2217(92)90288-K.

12. Khennane A.: Introduction to Finite Element Analysis Using MATLAB® and Abaqus. Taylor \& Francis Group, LLC, Boca Raton, 2013, http://dx.doi.org/10.1201/b15042.

13. Morecki A.: Podstawy robotyki. Teoria i elementy manipulatorów i robotów (in Polish). WNT, Warsaw 1999.

14. Nestor E. and Nava R. (eds): Advanced Mechanics in Robotic Systems. Springer-Verlag London Limited 2011.

15. Olszewski M.: Manipulatory i roboty przemysłowe (in Polish). WNT, Warsaw 1985.

16. Peter Marti: Theory of structures. Fundamentals framed structures, plates and shells. Wilhelm Ernst \& Sohn, Verlag für Architektur und technische Wissenschaften GmbH \& Co. KG, Berlin, Germany, 2013, http://dx.doi.org/10.1002/9783433602638.

17. Rakowski G., Kacprzyk Z.: Metoda elementów skończonych w mechanice konstrukcji (in Polish). Warsaw University of Technology Press, Warsaw 2005.

18. Rusiński E., Czmochowski J., Smolnicki T.: Zaawansowana metoda elementów skończonych w konstrukcjach nośnych (in Polish). Wroclaw University of Technology Press, Wroclaw 2000.

19. Yaohua He, Yong Wu, Robert de Souza: A global search framework for practical three-dimensional packing with variable carton orientations. Computers \& Operations Research 2012;39:2395-2414, http://dx.doi.org/10.1016/j.cor.2011.12.007.

20. Yu-Qiu Long, Song Cen and Zhi-Fei Long: Advanced Finite Element Method in Structural Engineering. Springer-Verlag GmbH Berlin Heidelberg, 2009, http://dx.doi.org/10.1007/978-3-642-00316-5.

\author{
Marek CHODURSKI \\ Department of Applied Mechanics, Lublin University of Technology \\ Nadbystrzycka 36, 20-618 Lublin, Poland

\section{Hubert DĘBSKI} \\ Department of Machine Design and Mechatronics, Lublin University of Technology \\ Nadbystrzycka 36, 20-618 Lublin, Poland
}

\section{Sylwester SAMBORSKI \\ Andrzej TETER}

Department of Applied Mechanics, Lublin University of Technology

Nadbystrzycka 36, 20-618 Lublin, Poland

E-mail: chodurski@wp.pl, h.debski@pollub.pl, s.samborski@pollub.pl, a.teter@pollub.pl 